\title{
Leading factors of market profitability of the renewable energy companies
}

\author{
Galina Chebotareva \\ Academic Department of Energy and Industrial Enterprises Management Systems \\ Ural Federal University \\ Mira str. 19, 620002, Ekaterinburg \\ Russian Federation \\ e-mail: galina_ch90@mail.ru
}

\begin{abstract}
Global investment into renewable energy sources (RES) development is setting new records in terms of volume. For several years, investment in new RES capacities have exceeded funds invested in conventional energy capacity. As a result, it is becoming a relevant task to know what reasons investors have for investing in renewable energy. The article presents the findings of a comprehensive analysis of the global renewable energy market from an investment perspective. The analysis enabled the author to identify the types of RES and countries with the maximum investment potential in this market. This paper presents a methodology for studying the dependence of RES companies' market profitability on a number of quantitative and qualitative indicators which constitute the leading factors of their development and growth. The methodology assesses a combination of companies' financial characteristics using econometric analysis methods. Expert estimation is used for assessing a number of specific risks of the industry. The practical evaluation was carried out on the basis of official data from 30 RES companies that hold leading positions in the market. The results of the study will be used in the development of a comprehensive model for assessing the investment potential of RES companies taking into account their regional peculiarities, the development of a methodology for studying the dependence of the return on investment in renewable energy, as well as for the purposes of the practical assessment of investment efficiency in this sector.
\end{abstract}

\section{Introduction}

Among the main factors influencing the potential market return and investment attractiveness of renewable energy projects, experts name (Konova et al. 2012; Lisin et al. 2014; Ermolenko 2016; Porfirev 2016; Rogalev et al. 2018; or Newbery et al. 2018): 1) government measures and quality of state support for the development of renewable energy; 2) financial performance of renewable energy companies; 3 ) the price at which the produced electricity can be sold; 4) the attractiveness of a particular country, etc.

The influence of many factors and the lack of experts' consensus on this issue lead to the emergence of a complex task of conducting not only a theoretical, but also an applied study of the factors that affect the investment attractiveness of RES companies (projects) based on their market return.

The result of the study is a comprehensive analysis of investment processes in the global renewable energy market in the regional and institutional aspects from the perspective of public and private investors by type of renewable energy, the input of new capacities, etc. The article presents a quantitative assessment of financial factors of market profitability of RES companies, as well as an assessment of the quality indicators impact (in the form of specific risks of the sector) on the investment attractiveness of companies. The study showed that the profitability of RES companies is sector-specific. This indicator does not depend on the main financial indicators of companies ' activity, but is subject to the influence of such qualitative characteristics as stability and predictability of the state policy aimed at stimulating the development of RES (political and legislative risks, etc.). The obtained results are of practical importance and will be used to improve the methodology for assessing the dependence of the return on investment in renewable energy, as well as the development of a methodical approach to assessing the investment potential of the industry.

\section{Investment in the global renewable energy market}

The current investment process in the field of renewable energy is characterized by the following features:

1. Growth of investments made by private investors in RES projects

2. An increase in the number of large commercial banks financing RES projects, as well as amount of loans issued 
3. The emergence of new financial instruments tailored to the renewable energy industry: green bonds, asset-backed securities, yield cos, crowdfunding, etc.

Table 1 that follows shows the dynamics of investments in the renewable energy market in 2005-2016:

Table 1. Global new investments in RES and renewable fuels by region (2005-16), \$ bln.

\begin{tabular}{|c|c|c|c|c|c|c|c|c|c|c|c|c|}
\hline Region & 2005 & 2006 & 2007 & 2008 & 2009 & 2010 & 2011 & 2012 & 2013 & 2014 & 2015 & 2016 \\
\hline USA & 11,9 & 29,1 & 33,2 & 35,5 & 23,9 & 34,7 & 49,0 & 40,6 & 35,3 & 37,0 & 44,1 & 46,4 \\
\hline Brazil & 3,1 & 5,2 & 11,4 & 11,8 & 7,9 & 7,2 & 10,2 & 7,7 & 4,4 & 8,0 & 7,1 & 6,8 \\
\hline $\begin{array}{l}\text { America } \\
\text { (except } \\
\text { USA and } \\
\text { Brazil) } \\
\end{array}$ & 3,3 & 3,7 & 5,0 & 6,1 & 5,5 & 12,0 & 9,3 & 10,1 & 12,0 & 13,3 & 12,8 & 6,1 \\
\hline $\begin{array}{l}\text { Africa and } \\
\text { the middle } \\
\text { East }\end{array}$ & 0,8 & 1,1 & 1,8 & 2,3 & 1,6 & 4,1 & 3,0 & 10,2 & 9,3 & 7,9 & 12,5 & 7,7 \\
\hline India & 3,0 & 4,9 & 6,7 & 5,6 & 4,3 & 8,8 & 12,8 & 7,8 & 6,6 & 8,3 & 10,2 & 9,7 \\
\hline China & 8,3 & 11,2 & 16,7 & 25,6 & 38,8 & 39,6 & 47,4 & 61,7 & 62,0 & 87,8 & 103 & 78,3 \\
\hline $\begin{array}{l}\text { APR (except } \\
\text { India and } \\
\text { China) }\end{array}$ & 9,0 & 10,0 & 12,4 & 13,6 & 13,9 & 19,3 & 23,8 & 30,2 & 44,4 & 48,8 & 47,6 & 26,8 \\
\hline Europe & 33,6 & 46,9 & 66,8 & 81,8 & 82,7 & 113,4 & 122,9 & 89,9 & 60,0 & 62,0 & 48,8 & 59,8 \\
\hline $\begin{array}{l}\text { WORLD } \\
\text { (TOTAL) }\end{array}$ & 73,0 & 112,1 & 154,0 & 182,3 & 178,6 & 239,1 & 278,4 & 258,2 & 234,0 & 273,1 & 286 & 241,6 \\
\hline
\end{tabular}

Source: REN 21 (2016); REN 21 (2017)

During that period, volume of new investments increased globally almost 3.5-fold (between 2005 and 2015 the growth was almost four-fold). Investments in the global market peaked in 2015 when the volume of investments in RES amounted to \$286 billion. Before that the maximum volume of investments was recorded in 2011 at $\$ 278.4$ billion. The main powerhouses of the investment growth in the market are such regions as China, the USA, other American countries, the APR countries, as well as Africa and the Middle East. At the end of 2015 they reported a growth of $12.4,3.7,3.9,5.3$ and 15.6 times respectively. However, in 2016 the investment performance of RES for all leading countries- dramatically slowed down.

An incremental growth in investments in renewable energy is largely driven by private investors rather than by public finance (Table 2). Thus, in 2015, the share of government (institutional) financing of RES was only $5.52 \%$, in $2011-7.28 \%$. The largest share of state support for RES in 2009-16 was recorded in 2012, exceeding $10 \%$. During the same period, the absolute value of public financing of RES in the world market also reached a maximum of $\$ 26.1$ billion. The structural distribution of public investment by institution is presented in Table 3.

Table 2. Public investment in renewable energy development (2009-16), \$ mln.

\begin{tabular}{|l|c|c|c|c|c|c|c|c|}
\hline Region & 2009 & 2010 & 2011 & 2012 & 2013 & 2014 & 2015 & 2016 \\
\hline Africa & 315 & 1580 & 1448 & 2571 & 1314 & 3464 & 1512 & 3196 \\
\hline Asia & 662 & 1344 & 3894 & 2499 & 2580 & 5164 & 3585 & 3981 \\
\hline $\begin{array}{l}\text { Central America } \\
\text { and the Caribbean }\end{array}$ & 357 & 524 & 271 & 779 & 562 & 940 & 1217 & 565 \\
\hline Eurasia & 272 & 232 & 337 & 439 & 100 & 1105 & 775 & 719 \\
\hline Europe & 3076 & 5460 & 5259 & 3343 & 4292 & 6186 & 4302 & 4494 \\
\hline Middle East & - & - & 3 & - & 218 & 740 & 309 & 208 \\
\hline North America & 111 & 288 & 635 & 18 & 115 & 433 & 41 & 65 \\
\hline Oceania & 6 & - & - & 1 & 20 & 32 & 28 & 7 \\
\hline South America & 11548 & 4662 & 7965 & 16291 & 5931 & 441 & 3461 & 2949 \\
\hline WORLD (TOTAL) & 16398 & 14092 & 20266 & $\mathbf{2 6 1 1 6}$ & 15760 & 22554 & 15790 & 16708 \\
\hline
\end{tabular}

Source: IRENA (2017a); IRENA (2017b)

The renewable energy sources that have attracted the biggest amount of investment are presented in Table 4. They account for an average of $6.7 \%$ of total global investments and more than $85 \%$ of public financing of RES. A global ranking of countries in terms of investment in RES development compiled by the Agency REN21 is presented in Table 3. 
Table 3. Volume of public investment of renewable energy (institutional aspect) (2009-16), \$ mln.

\begin{tabular}{|l|c|c|c|c|c|c|c|c|}
\hline Institute & 2009 & 2010 & 2011 & 2012 & 2013 & 2014 & 2015 & 2016 \\
\hline$A D B$ & 173 & 457 & 295 & 506 & 1080 & 1030 & 1985 & 1867 \\
\hline$A F D$ & 595 & 911 & 933 & 1367 & 587 & 1230 & 575 & 2 \\
\hline$A f D B$ & - & 55 & 492 & 934 & 398 & 720 & 634 & 2050 \\
\hline$B N D E S$ & 10385 & 3177 & 6389 & 15364 & 3552 & 2797 & 2338 & 1837 \\
\hline$C A B E I$ & - & 349 & 191 & 300 & 168 & 327 & 62 & 173 \\
\hline$C A F$ & 78 & 600 & 550 & 164 & 237 & 95 & 129 & - \\
\hline$E B R D$ & 277 & 633 & 58 & 520 & 351 & 1444 & 669 & 435 \\
\hline$E I B$ & 3061 & 4738 & 4009 & 2491 & 3943 & 5085 & 3157 & 3789 \\
\hline$F M O$ & - & 12 & 7 & 276 & 276 & 325 & 410 & 313 \\
\hline$G I B$ & - & - & - & 166 & 411 & 1566 & 1197 & 514 \\
\hline$I A D B$ & 1126 & 842 & 581 & 297 & 487 & 467 & 1189 & 844 \\
\hline$I F C$ & 208 & 587 & 346 & 482 & 892 & 889 & 653 & 378 \\
\hline$J B I C$ & - & - & 940 & 212 & 433 & 1383 & 519 & 581 \\
\hline$J I C A$ & - & 821 & 716 & - & 395 & 642 & 232 & 1021 \\
\hline KEXIM & - & 380 & 22 & 12 & 545 & 188 & 33 & - \\
\hline NIB & 141 & 349 & 977 & 674 & 388 & 727 & 321 & 344 \\
\hline OPIC & 19 & 111 & 1077 & 1021 & 1269 & 1487 & 632 & 895 \\
\hline WBG & 335 & 70 & 2015 & 1330 & 348 & 2152 & 1055 & 1664 \\
\hline $\begin{array}{l}\text { WORLD } \\
\text { (TOTAL) }\end{array}$ & 16398 & 14092 & 20266 & 26116 & 15760 & 22554 & 15790 & 16708 \\
\hline
\end{tabular}

Source: IRENA (2017a); IRENA (2017b) (highlights)

Table 4. Global volume of renewable energy financing by type of RES (2009-16), \$ mln.

\begin{tabular}{|l|c|c|c|c|c|c|c|c|}
\hline \multicolumn{1}{|c|}{ Type } & 2009 & 2010 & 2011 & 2012 & 2013 & 2014 & 2015 & 2016 \\
\hline Hydropower & 10015 & 3298 & 8146 & 17202 & 3922 & 5916 & 2411 & 1694 \\
\hline Wind energy & 2328 & 5469 & 5314 & 3800 & 5971 & 7585 & 4663 & 5308 \\
\hline Solar energy & 569 & 1135 & 2180 & 1938 & 1895 & 3280 & 1564 & 2705 \\
\hline Bioenergy & 2430 & 2478 & 1617 & 1378 & 1313 & 1473 & 1255 & 705 \\
\hline Geothermal energy & 258 & 982 & 953 & 128 & 458 & 1250 & 966 & 2121 \\
\hline TOTAL & 15600 & 13362 & 18210 & 24446 & 13559 & 19504 & 10859 & 12533 \\
\hline
\end{tabular}

Source: Renewable Energy Policy Network for the $21^{\text {st }}$ Centure. State of renewable energy 2016. Global report; Supporting the global transition to renewable energy. Global report 2017

Table 5. Top countries for investments in RES and new capacity (2016)

\begin{tabular}{|c|c|c|c|c|c|c|}
\hline \multicolumn{2}{|c|}{ Indicator Place in ranking } & 1 & 2 & 3 & 4 & 5 \\
\hline \multicolumn{2}{|c|}{ Investments in RES } & China & USA & Great Britain & Japan & Germany \\
\hline \multicolumn{2}{|c|}{ Investment in RES per unit of GDP } & Bolivia & Senegal & Jordan & Honduras & Iceland \\
\hline \multirow{6}{*}{ 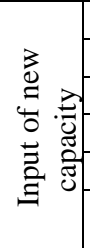 } & Geothermal energy & Indonesia & Turkey & Kenya & Mexico & Japan \\
\hline & Hydropower & China & Brazil & Ecuador & Ethiopia & Vietnam \\
\hline & Solar PV energy & China & USA & Japan & India & Great Britain \\
\hline & Solar CSP energy & SAR & China & - & - & - \\
\hline & Wind energy & China & USA & Germany & India & Brazil \\
\hline & Solar thermal energy & China & Turkey & Brazil & India & USA \\
\hline
\end{tabular}

Source: REN 21 (2016); REN 21 (2017)

Compared to 2015, the position of the European region has been improving. While China has maintained its status as the absolute leader in terms of investment in RES, Great Britain has swapped places with Japan, and Germany has come up fifth, displacing India. India also fell out of the ranking of installed hydropower capacity, and Japan lost one position in the development of solar PV energy. However, it is important to note that China 
has started to introduce solar CSP energy and it is for the first time that it has entered this ranking. India has improved its standing in terms of commissioning new wind energy capacity.

The analysis shows that the issue of further increasing investment in the global renewable energy market remains highly relevant. Regions continue to implement capital-intensive investment projects in the field of RES which require a sufficient amount of finance. However, governments in different countries have been mainly using indirect instruments to support this sector, and its share in the total investment does not exceed $8 \%$ on average. The resulting competition for private investment requires an examination of the factors that encourage investors to finance renewable energy.

\section{Market profitability of RES companies based on the systems of financial indicators}

The purpose of this approach is to quantify the dependence of the market profitability of RES companies on a number of financial indicators. The total sample size consisted of about 30 RES companies - world leaders whose shares are traded in the global financial market. The list includes First Solar Inc, Xinyi Solar Holdings Ltd, Sunpower Corp, Gintech Energy Corp and others. Primary data for the assessment was collected from the companies' official reports formatted as per the Securities and Exchange Commission guidelines, as well as the world financial market statistics for 2014-16. As a dependent variable, the annual profitability of RES companies was chosen, which takes into account all seasons of its operation.

The method of assessing the profitability by financial indicator. The quantitative assessment of the market profitability of RES companies is based on the study of the dependence of the final profitability indicator "Stock chg" on a number of private financial values, which are widely used in the world practice:

capital
the amount of its operating profit, depreciation and amortization.

Practical assessment of RES companies profitability by financial indicator. Figures 1 and 2 presents the graphic interpretation of the dependence of the profitability of RES companies on individual values for 20152016.
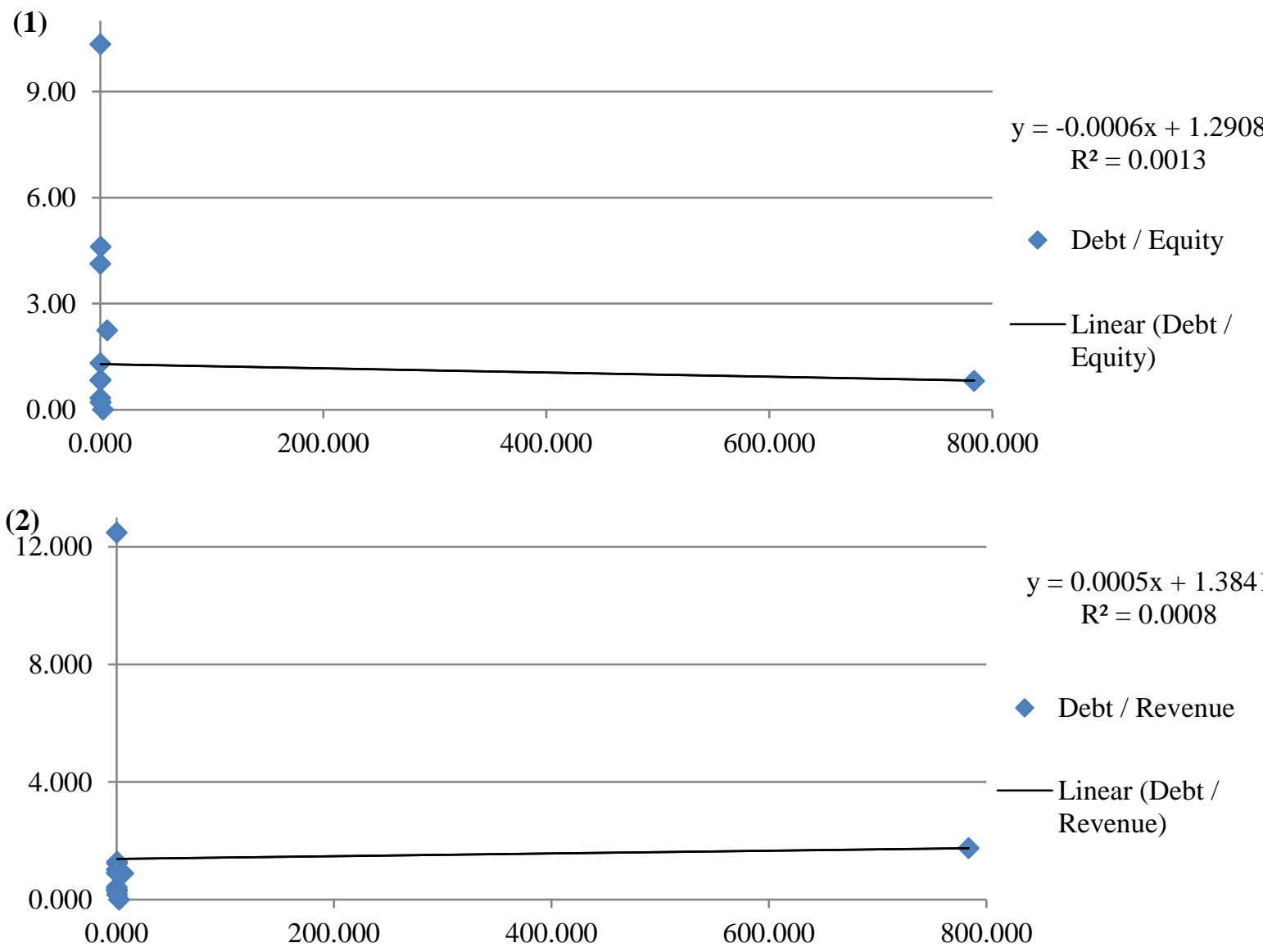


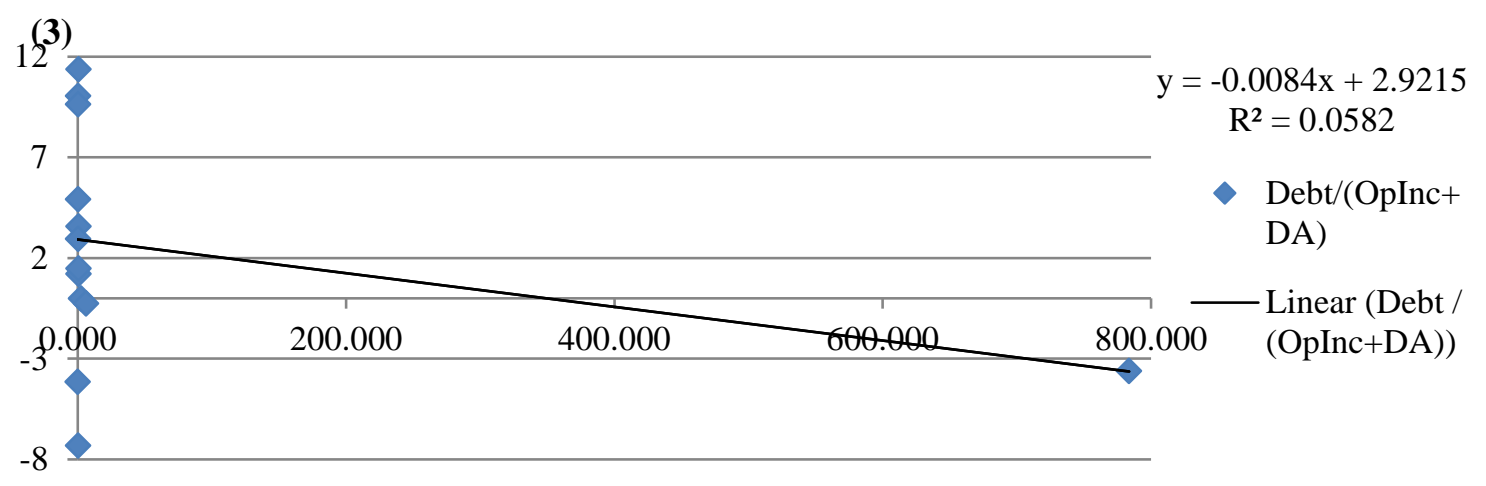

Fig.1. The dependence of the market profitability of RES companies on the indicators: Debt / Equity (1), Debt / Revenue (2) и Debt / (OpInc+DA) (3) for 2015 Source: Own results
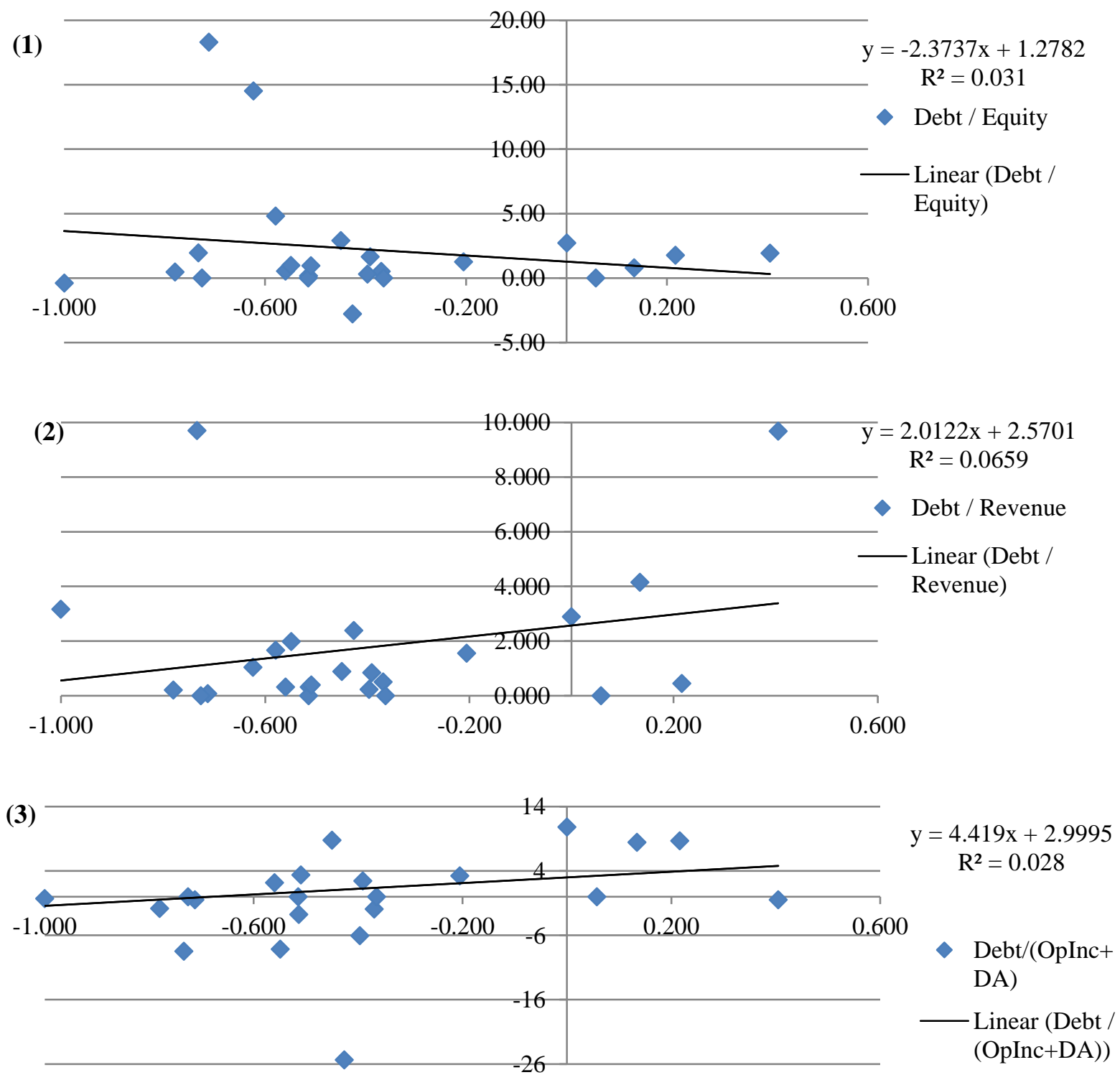

Fig.2. The dependence of the market profitability of RES companies on the indicators: Debt / Equity (1), Debt / Revenue (2) и Debt / (OpInc+DA) (3) for 2016 Source: Own results 
An evaluation of the reliability of the obtained models is conducted in terms of correlation (R), approximation (R2), as well as F-ratio test and Student t-test number (Table 6).

Table 6. Evaluation of the reliability of the profitability models of RES companies

\begin{tabular}{|c|c|c|c|c|c|c|c|c|c|c|}
\hline \multirow{2}{*}{$\stackrel{\Xi}{\Xi}$} & \multirow{2}{*}{ Indicator } & \multicolumn{4}{|c|}{ Actual values of the criteria } & \multicolumn{5}{|c|}{ Normative (critical) values } \\
\hline & & $R$ & $R^{2}$ & $\begin{array}{c}F \text {-ratio } \\
\text { test }\end{array}$ & $\begin{array}{c}\text { t-test } \\
\text { number }\end{array}$ & $\begin{array}{c}R \\
p= \\
0,05\end{array}$ & $\begin{array}{c}R \\
p= \\
0,001\end{array}$ & $\begin{array}{c}F_{1-\alpha} \\
\alpha= \\
0,10\end{array}$ & $\begin{array}{c}F_{1-\alpha} \\
\alpha= \\
0,05\end{array}$ & $\begin{array}{c}t \\
p= \\
0,05\end{array}$ \\
\hline \multirow{3}{*}{$\stackrel{n}{\frac{n}{2}}$} & Debt / Equity & $-0,036$ & 0,001 & 0,028 & 0,337 & \multirow{6}{*}{$\begin{array}{l}0,43 / \\
-0,43\end{array}$} & \multirow{6}{*}{$\begin{array}{l}0,67 / \\
-0,67\end{array}$} & \multirow{6}{*}{2,96} & \multirow{6}{*}{4,33} & \multirow{6}{*}{2,080} \\
\hline & Debt / Revenue & 0,029 & 0,0008 & 0,017 & 0,339 & & & & & \\
\hline & Debt/(OpInc+DA) & $-0,241$ & 0,058 & 1,297 & 0,358 & & & & & \\
\hline \multirow{3}{*}{$\frac{0}{0}$} & Debt / Equity & $-0,176$ & 0,031 & 0,673 & 0,008 & & & & & \\
\hline & Debt / Revenue & 0,257 & 0,066 & 1,482 & 0,0003 & & & & & \\
\hline & Debt/(OpInc+DA) & 0,167 & 0,028 & 0,605 & 0,383 & & & & & \\
\hline
\end{tabular}

Source: Own results based on Gmurman (1997)

According to the results of the calculations for the total sample size the following conclusions were obtained: in 2015:

- $\quad$ Between the variables Debt / Equity and Stock chg there is no connection

- $\quad$ Between the variables Debt / Revenue and Stock chg there is no connection

- $\quad$ Between the Debt/(OpInc+DA) and Stock chg variables there is a weak feedback connection

- $\quad$ The hypothesis of the reliability of models is generally rejected by F-ratio test for all levels of significance

- The hypothesis of the reliability of the models is rejected by Student t-test. In 2016:

- $\quad$ Between Debt / Equity and Stock chg variables there is an extremely weak feedback connection

- Between the Debt / Revenue and Stock chg variables there is a weak direct connection

- Between the Debt/(OpInc+DA) and Stock chg variables there is an extremely weak direct connection

- The hypothesis of the reliability of models is generally rejected by F-ratio test for all levels of significance

- $\quad$ The hypothesis of the reliability of the models is rejected by Student t-test.

Thus, the quantitative assessment did not reveal the dependence of the market profitability of RES companies on its main financial values. It indicates that the liquidity of shares of companies in the industry is low. Therefore, even small amounts of capital investment can trigger a strong change in market returns that is not correlated with the main financial indicators of the sector's companies.

In the current market conditions, the results can only be determined by the specifics of the industry and the dependence of the attractiveness of RES companies on a number of qualitative factors. It may be due to the high level of state support, including policy measures in relation to renewable energy: tax, financial, price and other benefits to RES producers and investors in this sector.

\section{Qualitative approach to assessment of market profitability of RES companies}

The qualitative assessment of factors influencing the market profitability of RES companies is based on an expert study of risks characterizing this sector. The experts were representatives of the services and departments of Russian energy companies, as well as employees of Ural Federal University with expertise in in the field of renewable energy and energy saving.

The method of qualitative assessment of market profitability. The presented expert evaluation involves ranking the identified risks as per their impact on the market profitability of the company. The ranking criteria are: the level of risk impact on profitability $(\gamma)$, maximum $\left(\mathrm{p}^{\max }\right)$ and minimum $\left(p^{\min }\right)$ probability of risk occurrence (Domnikov 2014). The experts used a rating scale presented in Table 7. 
Table 7. Characteristics of risk ranking criteria

\begin{tabular}{|c|c|c|c|}
\hline $\mathrm{N}$ & Criteria & Rating scale & Ass \\
\hline 1 & $\begin{array}{l}\text { Level of risk impact } \\
\text { on RES company } \\
\text { profitability }(\boldsymbol{\gamma}, \\
\text { degree })\end{array}$ & $\begin{array}{l}\text { Up to } 15 \text {-weak degree of influence } \\
15-30 \text {-moderate degree of influence } \\
31 \text { - } 45 \text { - significant impact } \\
46 \text { - } 60 \text { - a strong degree of influence } \\
61 \text { - } 75 \text { - critically strong degree of influence } \\
76 \text { - } 90 \text { - catastrophically strong degree }\end{array}$ & $\begin{array}{l}\text { Measured in the range from } 0 \text { to } \\
\qquad 90 \text { degrees }\end{array}$ \\
\hline 2 & $\begin{array}{l}\text { bability of each } \\
\left(\mathbf{p}^{\text {max }}, \%\right)\end{array}$ & \multirow{2}{*}{$\begin{array}{l}0-10 \% \text { - the lowest probability of risk } \\
11-20 \% \text { - low probability } \\
21-30 \% \text { - average probability } \\
30-50 \% \text { - high probability } \\
\text { More than } 50 \% \text { - ultra-high probability, leads } \\
\text { to loss of profitability }\end{array}$} & $\begin{array}{r}100 \% \text {. Alw } \\
\text { minimun }\end{array}$ \\
\hline 3 & $\begin{array}{l}\text { Minimum } \\
\text { probability of each } \\
\text { risk }\left(p^{\min }, \%\right)\end{array}$ & & $\begin{array}{l}\text { Measured in the range from } 0 \text { to } \\
100 \% \text {. Always no more than the } \\
\text { maximum probability }\end{array}$ \\
\hline
\end{tabular}
Source: Domnikov (2014)

Practical assessment of impact of specific risks on RES companies' profitability. The list of identified risks, reflecting the specific features of renewable energy sources and the characteristics of the sector are presented in Table 8.

Table 8. Specific risks in RES industry

\begin{tabular}{|c|c|c|}
\hline Risks' title & Symbol & Characteristic \\
\hline Incorrect placement of RES installations & $r_{1}$ & Inefficient regional distribution of renewable energy facilities \\
\hline Legislative risks & $r_{2}$ & $\begin{array}{l}\text { Instability of the mechanisms of government support of RES } \\
\text { projects leads to the emergence of legislative risks }\end{array}$ \\
\hline $\begin{array}{l}\text { Dependence of investors on } \\
\text { government support }\end{array}$ & $r_{3}$ & $\begin{array}{l}\text { At all stages of a project. Usually this is due to the volume } \\
\text { and duration of the support being provided }\end{array}$ \\
\hline $\begin{array}{l}\text { Low efficiency of the mechanisms of } \\
\text { government and regional incentives }\end{array}$ & $r_{4}$ & $\begin{array}{l}\text { Frequent changes in support schemes contribute to the low } \\
\text { efficiency of the mechanisms of government and regional } \\
\text { incentives for RES development in some areas (Daniilidis } \\
\text { 2017) }\end{array}$ \\
\hline High cost of RES & $r_{5}$ & $\begin{array}{l}\text { Higher adjusted cost of renewable energy (LCOE) compared } \\
\text { to traditional energy sources (Ghoddusi 2017) }\end{array}$ \\
\hline $\begin{array}{l}\text { Low effectiveness of adoption of RES } \\
\text { technologies }\end{array}$ & $r_{6}$ & $\begin{array}{l}\text { In comparison with the cost of replacement or repair of worn- } \\
\text { out basic production assets of energy companies / adoption of } \\
\text { new conventional energy technologies (Budischak 2013) }\end{array}$ \\
\hline Reduction in private investment & $r_{7}$ & Low effective and investment attractiveness (Deloitte 2014) \\
\hline Environmental risks & $r_{8}$ & $\begin{array}{l}\text { An increase in energy companies' expenditures on } \\
\text { environmental safety measures compared to conventional } \\
\text { energy sources }\end{array}$ \\
\hline Slow pace of RES market development & $r_{9}$ & $\begin{array}{l}\text { Share of renewable energy in the energy balance, share of } \\
\text { electricity generated by RES, "natural" demand on renewable } \\
\text { energy }\end{array}$ \\
\hline $\begin{array}{l}\text { High pace of conventional energy } \\
\text { market development }\end{array}$ & $r_{10}$ & $\begin{array}{l}\text { The volume of current and prospective hydrocarbon reserves. } \\
\text { It has a direct influence on demand, the cost of electricity and } \\
\text { efficiency of RES projects }\end{array}$ \\
\hline Fossil fuel subsidy & $r_{11}$ & Distorts the real cost of energy (REN 21 2016) \\
\hline $\begin{array}{l}\text { Slow pace of distributed power } \\
\text { generation development in RES }\end{array}$ & $r_{12}$ & $\begin{array}{l}\text { Slow pace of distributed power generation development in the } \\
\text { RES sphere }\end{array}$ \\
\hline Shortage of qualified personnel & $r_{13}$ & $\begin{array}{l}\text { Shortage of qualified personnel in various areas of RES (REN } \\
21 \text { 2016) }\end{array}$ \\
\hline Low consumer confidence $t$ & $r_{14}$ & $\begin{array}{l}\text { Low consumer confidence and lack of awareness of } \\
\text { renewable energy alternatives (REN } 212016 \text { ) }\end{array}$ \\
\hline
\end{tabular}

Source: Chebotareva (2018) 
The ranking of risks was done by experts for Asia, North America and Europe. According to the results of the evaluation, the following total average rating of sector-specific risks by the level of impact on the market profitability of RES companies was obtained (Table 9).

The calculated Kendall concordance coefficient for each of the regions is within the limits $[0.8 ; 1.0]$ and indicates the consistency of the experts ' opinions.

Table 9. Ranking of specific risks in RES

\begin{tabular}{|c|c|c|c|c|c|c|c|c|c|c|c|c|c|}
\hline \multirow[b]{2}{*}{$\mathrm{N}$} & \multirow[b]{2}{*}{$\begin{array}{l}\text { Final } \\
\text { place }\end{array}$} & \multicolumn{4}{|c|}{ Ranking for Asia } & \multicolumn{4}{|c|}{ Ranking for North America } & \multicolumn{4}{|c|}{ Ranking for Europe } \\
\hline & & $\mathrm{N}$ & $\gamma$ & $\begin{array}{c}p^{\max }, \\
\%\end{array}$ & $\begin{array}{c}p^{\text {min }}, \\
\%\end{array}$ & $\mathrm{~N}$ & $\gamma$ & $\begin{array}{c}p^{\max }, \\
\%\end{array}$ & $\begin{array}{c}p^{\min }, \\
\%\end{array}$ & $\mathrm{~N}$ & $\gamma$ & $\begin{array}{c}p^{\max }, \\
\%\end{array}$ & $\begin{array}{c}p^{\min } \\
\%\end{array}$ \\
\hline 1 & $\mathbf{r}_{13}$ & $\mathbf{r}_{10}$ & 45 & 35 & 20 & $\mathbf{r}_{10}$ & 55 & 35 & 20 & $\mathbf{r}_{13}$ & 50 & 40 & 20 \\
\hline 2 & $\mathbf{r}_{10}$ & $\mathbf{r}_{13}$ & 40 & 30 & 18 & $\mathbf{r}_{13}$ & 50 & 40 & 20 & $\mathbf{r}_{7}$ & 50 & 10 & 5 \\
\hline 3 & $\mathbf{r}_{1}$ & $\mathbf{r}_{1}$ & 30 & 15 & 5 & $\mathbf{r}_{11}$ & 40 & 35 & 25 & $\mathbf{r}_{2}$ & 50 & 7 & 3 \\
\hline 4 & $\mathbf{r}_{11}$ & $\mathbf{r}_{3}$ & 30 & 15 & 5 & $\mathbf{r}_{1}$ & 35 & 24 & 8 & $\mathbf{r}_{1}$ & 45 & 30 & 10 \\
\hline 5 & $\mathbf{r}_{7}$ & $\mathbf{r}_{6}$ & 25 & 23 & 10 & $\mathbf{r}_{5}$ & 30 & 17 & 10 & $\mathbf{r}_{3}$ & 45 & 10 & 2 \\
\hline 6 & $\mathbf{r}_{3}$ & $\mathbf{r}_{11}$ & 20 & 20 & 10 & r6 & 28 & 20 & 10 & $\mathbf{r}_{10}$ & 40 & 30 & 15 \\
\hline 7 & $\mathbf{r}_{6}$ & $\mathbf{r}_{12}$ & 20 & 15 & 9 & $\mathbf{r}_{4}$ & 25 & 15 & 8 & $\mathbf{r}_{11}$ & 40 & 20 & 7 \\
\hline 8 & $\mathbf{r}_{2}$ & $\mathbf{r}_{14}$ & 20 & 10 & 7 & $\mathbf{r}_{7}$ & 25 & 12 & 5 & $\mathbf{r}_{4}$ & 35 & 8 & 5 \\
\hline 9 & $\mathbf{r}_{4}$ & $\mathbf{r}_{7}$ & 20 & 10 & 5 & r9 & 20 & 15 & 5 & $\mathbf{r}_{12}$ & 30 & 15 & 3 \\
\hline 10 & $\mathbf{r}_{5}$ & $\mathbf{r}_{5}$ & 15 & 15 & 9 & $\mathbf{r}_{2}$ & 20 & 5 & 3 & $\mathbf{r}_{6}$ & 25 & 25 & 15 \\
\hline 11 & $\mathbf{r}_{14}$ & $\mathbf{r}_{8}$ & 15 & 15 & 3 & $\mathbf{r}_{14}$ & 15 & 15 & 7 & $\mathbf{r}_{14}$ & 25 & 25 & 12 \\
\hline 12 & $\mathbf{r}_{12}$ & r9 & 15 & 10 & 3 & r8 & 15 & 15 & 3 & $\mathbf{r}_{5}$ & 20 & 20 & 8 \\
\hline 13 & $\mathbf{r}_{9}$ & $\mathbf{r}_{4}$ & 10 & 5 & 1 & $\mathbf{r}_{3}$ & 15 & 7 & 3 & r9 & 20 & 12 & 5 \\
\hline 14 & $\mathbf{r}_{8}$ & $\mathbf{r}_{2}$ & 5 & 4 & 1 & $\mathbf{r}_{12}$ & 10 & 8 & 3 & $\mathbf{r}_{8}$ & 15 & 15 & 3 \\
\hline
\end{tabular}

Source: Own results

The calculations showed that, according to the experts, the greatest impact on the market profitability of RES companies is produced by the shortage of qualified personnel $\left(\mathrm{r}_{13}\right)$ : it ranks first in the European ranking, and second in Asia and North America. The risks associated with the high pace of conventional energy market development $\left(\mathrm{r}_{10}\right)$, which is in the second place in the ranking, are the most relevant for Asia and North America (first place), while for European countries are only in the sixth place. Among the top five risks there is incorrect placement of RES installations $\left(\mathrm{r}_{1}\right)$. Among the risks that uniformly showed minimal impact were: environmental risks $\left(\mathrm{r}_{8}\right)$ and low consumer confidence to RES $\left(\mathrm{r}_{14}\right)$. The specific features of the sector are best reflected by the political risks associated with the dependence of investors on government support $\left(\mathrm{r}_{3}\right)$. They pose the biggest threat to Asia and Europe (fourth and fifth places respectively), while in America they hold the last but one spot. This is primarily due to the fact that special attention to this sector in the USA was paid only from 2007 to 2009 , but no new measures of government support have been provided since 2010. At the same time, both in European and Asian countries, support for renewable energy is one of the priority areas of the economy (Brummer 2018; Liu 2018; Mittlefehldt 2018; or Sueyoshi 2018).

An assessment of sector-specific risks in RES investment projects within the framework of the Dia-Core project in the EU countries (Dia-Core 2016) based on data for more than 650 market participants surveyed made it possible to identify the biggest threats (Figure 3). The experts were representatives of the electric power industry, developers and investors of renewable energy projects, developers of technologies and manufacturers of renewable energy equipment, representatives of banks, public organizations and public institutions in all member states and candidates for EU membership.

The obtained results confirmed the specific characteristics of renewable energy: political risk is recognized as the biggest hazard. It implies a high dependence on the state regulation of the industry, unstable support for investors, sudden changes in legislation, etc. Financial risks, however, occupy one of the last places in this ranking.

\section{Conclusions}

The social significance of the "green energy" development throughout the world implies one has to sacrifice the economic efficiency of RES projects at the initial stages of their implementation. However, this mechanism is possible only in the conditions of direct state financing of the industry. For private investors, who account for the biggest share of funds available in the world of renewable energy, making a profit is one of the main goals. 
(1)

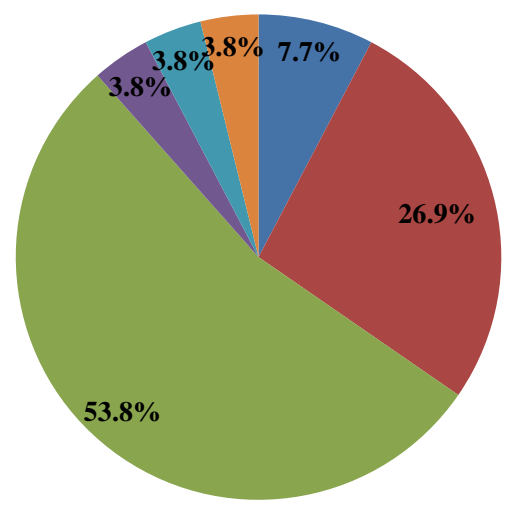

(3)

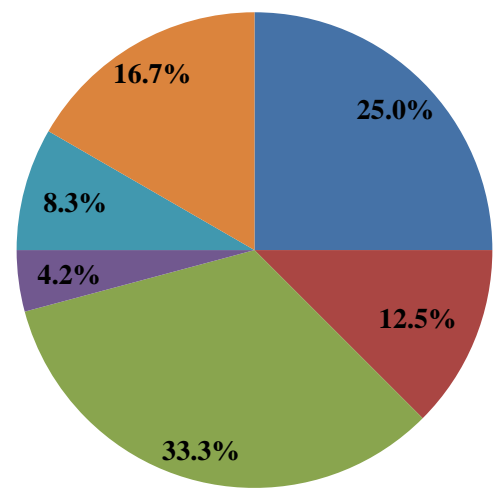

(2)

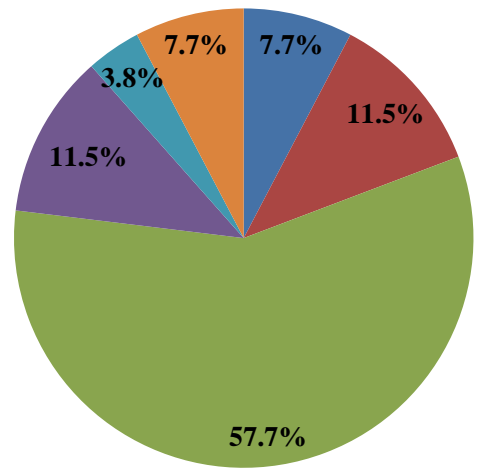

Fig.3. Rankings of RES risks by the level of hazards (EU countries): first (1), second (2) and third levels (3) Source: Ermolenko (2016)

The study showed that the renewable energy sector is quite peculiar from an investor's perspective. Its market profitability is formed not under the influence of financial indicators, but depends on the degree of stability and predictability of policies stimulating the development of RES in each country. The quantitative assessment showed that the market profitability of the largest RES companies and the indicators of Debt/Equity, Debt/Revenue, Debt/(OpInc+DA) either have a weak connection or there is no dependence at all. The qualitative assessment showed that the main risks affecting the profitability of companies in the industry are the shortage of qualified personnel, a high pace of conventional energy market development, as well as a number of risks associated with political support for the renewable energy sector. Studies conducted as part of the Dia-Core project in the EU countries confirmed the results.

Further directions of this study are related to the improvement of the methodology for assessing the dependence of the profitability of investments in renewable energy on a number of factors. A comprehensive assessment involves the consideration in a single model of:

- political risks

- $\quad$ territorial features

- $\quad$ the growth potential of RES energy consumption

- $\quad$ readiness of infrastructure for the acceptance of RES energy

- the level of investment attractiveness of a particular country

- financial performance of companies and investment projects in the field of renewable energy.

In the future, it will allow for a comprehensive study of not only social, but also economic attractiveness of RES projects in different regions and make it possible to assess the investment potential of these regions and companies in the sector, to study the effectiveness of government measures aimed at stimulating renewable energy adoption and to identify the stage at which RES projects will not need political support.

\section{Acknowledgements}

The work was supported with a grant of the Russian Science Foundation (project № 17-78-10039). 


\section{References}

Brummer V (2018) Community energy - benefits and barriers: A comparative literature review of Community Energy in the UK, Germany and the USA, the benefits it provides for society and the barriers it faces. Renewable and Sustainable Energy Reviews 94:187-196. doi: 10.1016/j.rser.2018.06.013

Budischak C, Sewell D, Thomson H, Mach L, et al. (2013) Cost-minimized combinations of wind power, solar power and electrochemical storage, powering the grid up to $99.9 \%$ of the time. Journal of Power Sources 225 : 60-74. doi: 10.1016/j.jpowsour.2012.09.054

Chebotareva G (2017) Researching the risks of Russian energy companies in the context of renewable energy sources development. WIT Transactions on Ecology and the Environment 224:45-56. doi:10.2495/ESUS170051

Daniilidis A, Herber R (2017) Impact of technical and economic uncertainties on the economic performance of a deep geothermal heat system. Renewable Energy 114(B): 805-816. doi: 10.1016/j.renene.2017.07.090

Deloitte Establishing the Investment Case: Wind Power. http://tinyurl.com/deloitte-wind-investment-2014. Accessed 01 Apr 2018.

Dia-Core project (2016) The impact of risks in renewable energy investment and the role of smart policies. http://diacore.eu/results/item/enhancing-res-investments-final-report. Accessed 01 June 2018.

Domnikov A, Chebotareva, G, Khodorovsky M (2014) Evaluation of investor attractiveness of power-generating companies: special reference to the development risks of the electric power industry. WIT Transactions on Ecology and the Environment 190(1):199-210. doi: 10.2495/EQ140211

Ermolenko GV, Tolmacheva IS, Ryapin IY, Fetisova YA, Matshura AA, Reutiva AB, Handbook on renewable energy the European Union, 1st edn. (Moscow, Russia: Institute of Energy SRU GSE, 2016), 96 p.

Ghoddusi H (2017) Price risks for biofuel producers in a deregulated market. Renewable Energy 114(B):394407. doi: 10.1016/j.renene.2017.07.044

Gmurman V, Probability theory and mathematical statistics, 1st edn. (Moscow, Russia: Higher School, 1997), $479 \mathrm{p}$.

International Renewable Energy Agency (IRENA) (2017a) Renewable energy highlights. http://www.irena.org/DocumentDownloads/Publications/IRENA_Renewable_energy_highlights_July_2017.pdf. Accessed 10 Feb 2018.

International Renewable Energy Agency (IRENA) (2017b) Renewable Energy Statistics 2017. http://www.irena.org/DocumentDownloads/Publications/IRENA_Renewable_Energy_Statistics_2017.pdf. Accessed 10 Jan 2018.

Konova O, Komarov I, Lisin E (2012) The relevance of power generating capacities based on the combined cycle power plants of high power. Czech Journal of Social Sciences, Business and Economics 1(1):101-109. doi: 10.24984/cjssbe.2012.1.1.11

Lisin E, Lebedev I, Sukhareva E., Komarov, I (2014) Analysis of scenario of structural and technological modernization of the power industry in the context of competitive electricity markets. International Economics Letters 3(3):105-114. doi: 10.24984/iel.2014.3.3.3

Liu Z (2018) What is the future of solar energy? Economic and policy barriers. Energy Sources, Part B: Economics, Planning and Policy 13(3): 169-172. doi: 10.1080/15567249.2017.1416704

Mittlefehldt S (2018) From appropriate technology to the clean energy economy: renewable energy and environmental politics since the 1970s. Journal of Environmental Studies and Sciences 8(2): 21-219. doi: 10.1007/s13412-018-0471-z

Newbery D, Pollitt MG, Ritz RA, Strielkowski W (2018) Market design for a high-renewables European electricity system. Renewable and Sustainable Energy Reviews 91:695-707. doi: 10.1016/j.rser.2018.04.025

Porfirev B N (2016) Green trends in the global financial system. World economy and International Relations 60(9):5-16. doi:10.20542/0131-2227-2016-60-9-5-16

Renewable Energy Policy Network for the $21^{\text {st }}$ Centure (REN21). State of renewable energy 2016. Global report. http://www.ren21.net/wp-content/uploads/2016/10/REN21_GSR2016_KeyFindings_RUSSIAN.pdf. Accessed 11 Feb 2018. 
Renewable Energy Policy Network for the $21^{\text {st }}$ Centure (REN21). Supporting the global transition to renewable energy. Global report 2017. http://www.ren21.net/wp-content/uploads/2017/10/17-8399_GSR 2017_KEYFINDINGS_RU_low.pdf. Accessed 20 Mar 2018

Rogalev A, Komarov I, Kindra V, Zlyvko O (2018) Entrepreneurial assessment of sustainable development technologies for power energy sector. Entrepreneurship and Sustainability Issues 6(1):429-445. doi: 10.9770/jesi.2018.6.1(26)

Sueyoshi T, Yuan Y (2018) Measuring energy usage and sustainability development in Asian nations by DEA intermediate approach. Journal of Economic Structures 7(1):6. doi: 10.1186/s40008-017-0100-0 